DOI: 10.34185/1991-7848.itmm.2020.01.006

УДК 629.78

\title{
ЗАСТОСУВАННЯ МЕТОДІВ РУХОМОГО КЕРУВАННЯ ДЛЯ СТАБІЛІЗАЦІЇ КОСМІЧНОГО АПАРАТУ 3 АЕРОМАГНІТНОЮ СИСТЕМОЮ ВІДВЕДЕННЯ
}

Лапханов Е. О., аспірант відділу Системного аналізу і проблем керування

$$
\text { Інститут технічної механіки НАНУ і ДКАУ, Україна }
$$

Анотація: В роботі проведено дослідження застосування методів рухомого керування для здійснення грубої стабілізації космічного апарату (КА) з аеромагнітною системою відведення (АМСB).

В свою чергу, АМСВ складається з двох підмодулів: аеродинамічного плоского вітрильного елементу i електромагнітних виконавчих органів. Електромагнітні виконавчі органи слугують для здійснення орієнтації і стабілізації аеродинамічного плоского вітрильного елементу перпендикулярно до динамічного потоку атмосфери, що набігає. Встановлено, що забезпечення такої стабілізації для плоских вітрильних аеродинамічних елементів збільшує силу аеродинамічного гальмування на 40-50 \% і зменшує час відведення на 25-30 \%. Однак, для ефективного функціонування таких систем, головним критерієм $є$ мінімізація витрат бортової електричної енергії в довготривалих космічних місіях 3 відведення відпрацьованих КА з робочих орбіт.

Виходячи 3 цього, було запропоновано застосування методів рухомого керування для електромагнітних виконавчих органів (магнетторків) за допомогою яких здійснюється груба стабілізація аеродинамічного елементу. Встановлено, що при застосуванні методів рухомого керування витрати бортової енергії можна на порядок зменшити.

Ключові слова: КОСМІЧНИЙ АПАРАТ, АЕРОМАГНІТНА СИСТЕМА ВІДВЕДЕННЯ, АЕРОДИНАМІЧНИЙ ПЛОСКИЙ ВІТРИЛЬНИЙ ЕЛЕМЕНТ, МЕТОДИ РУХОМОГО КЕРУВАННЯ.

Вступ. Розробка ефективних систем керування і пошук оптимальних алгоритмів керування є однією із головних задач в ракетно-космічній техніці. Із врахуванням певних обмежень та вимог в космічних місіях, здійснюється вибір необхідних виконавчих органів для космічного апарату (KA) i проводиться синтез відповідного закону керування. Так, в задачі відведення відпрацьованого КА за допомогою аеромагнітної системи відведення (АМСВ) 
International scientific and technical conference Information Technologies in Metallurgy and Machine building - ITMM 2020

постає питання здійснення грубої стабілізації аеродинамічного плоского вітрильного елементу перпендикулярно до динамічного потоку атмосфери, що набігає [1]. Встановлено, що забезпечення такої стабілізації збільшує силу аеродинамічного гальмування на 40-50 \% і зменшує час відведення на 25-30 \%.

Однак конструкція АМСВ 3 виконавчими органами 3 постійними поворотними магнітами, що запропонована в роботі [1] не підходить для КА 3 дуже щільною компоновкою корисного навантаження. Виходячи 3 цього, для розширення меж ефективного застосування АМСВ, було запропоновано використання додаткового ресурсу електромагнітних керуючих органів (магнетторків), що входять до основного складу органів системи орієнтації і стабілізації багатьох КА. В свою чергу, слід зазначити, що головним критерієм ефективного застосування виконавчих органів для стабілізації КА з АМСВ $є$ мінімізація витрат бортової електричної енергії. Так, значно менші витрати бортової енергії для магнетторків спостерігаються при застосуванні методів рухомого керування [2]. Проте мінімальні витрати бортової енергії при застосуванні цих методів спостерігаються лише в режимі грубої стабілізації. Дослідження [1] показали, що надання грубої одновісної стабілізації 3 максимальною похибкою 0,2 радіани в каналах рискання i тангажу задовольняють умовам ефективного застосування АМСВ. Враховуючи це, в роботі пропонується застосування методів рухомого керування для здійснення грубої тривісної стабілізації КА з АМСВ при заданій похибці в 0,2 радіани.

Основна частина. Принцип методів рухомого керування базується на застосуванні декількох контурів керування і функції переключання [2]. Так, в кожен момент часу активується лише один контур керування, всі інші контури залишаються неактивованими. Далі може відбуватися активація іншого контуру завдяки застосування спеціальної функції переключення. Виходячи 3 цього, головною відмінністю методів рухомого керування від традиційних методів є задіяння лише одного контуру (входу) керування в кожен момент часу [3]. В традиційних методах керування можна задіяти одночасно всі контури.

Так, було встановлено, що при почерговому ввімкненні трьох контурів керування при застосуванні магнетторків витрати бортової енергії знижуються на порядок. В свою чергу, такий метод працює при працездатному стані всіх трьох магнетторків, що розміщуються вздовж головних осей інерції КА. Звідси, схему керування можна представити у такому вигляді: 


$$
\left.\begin{array}{l}
M_{\text {кер.магн.х }}=\operatorname{sgn}\left(\delta_{y}\right) \cdot p_{\text {mуе }} \cdot B_{z} \\
M_{\text {кер.магн.y }}=-\operatorname{sgn}\left(\delta_{x}\right) \cdot p_{\text {mхе }} \cdot B_{z} \\
M_{\text {магн.z }}=\operatorname{sgn}\left(\delta_{x}\right) \cdot p_{m x e} \cdot B_{y}-\operatorname{sign}\left(\delta_{y}\right) \cdot p_{\text {mye }} \cdot B_{x}
\end{array}\right\} \rightarrow \text { конTyр-I }
$$

де контури I, II, III - контури керування, що переключаються за певним алгоритмом - функцією переключання; $p_{\text {тхе }}, p_{\text {mуе }}, p_{\text {mze }}$ - магнітні дипольні моменти магнетторків; $B_{x}, B_{y}, B_{z}$ - проекції вектору магнітної індукції магнітного поля Землі на осі зв’язаної з центром мас КА системи координат; $\delta_{x}, \delta_{y}, \delta_{z}$ - аргументи функції переключення, що слугують для зміни знаку при дії функції sgn (зміна полярності магніту - зміна напрямку струму у електромагнітному контурі або котушці); $M_{\text {магн.х }}, M_{\text {магн.у }}, M_{\text {магн.z }}-$ моменти збурень, що виникають у зв'язаних каналах при включенні певного контуру.

$M_{\text {кер.магн.х }}, M_{\text {кер.магн.y }}, M_{\text {кер.магн.z }}-$ керуючі магнітні моменти в каналах контурів I, II, III.

Особливістю застосування магнетторків $є$ наявність збурення в третьому каналі при здійснення керування в двох інших. Звідси, постає питання здійснення своєчасного переключання каналів для збереження стійкості системи. Функція переключання, змінює контур керування при поточному відхиленні значень кутів крену, рискання чи тангажу в певному каналі на встановлене значення помилки. Так функцію переключання для алгоритму (1) можна представити в такому вигляді:

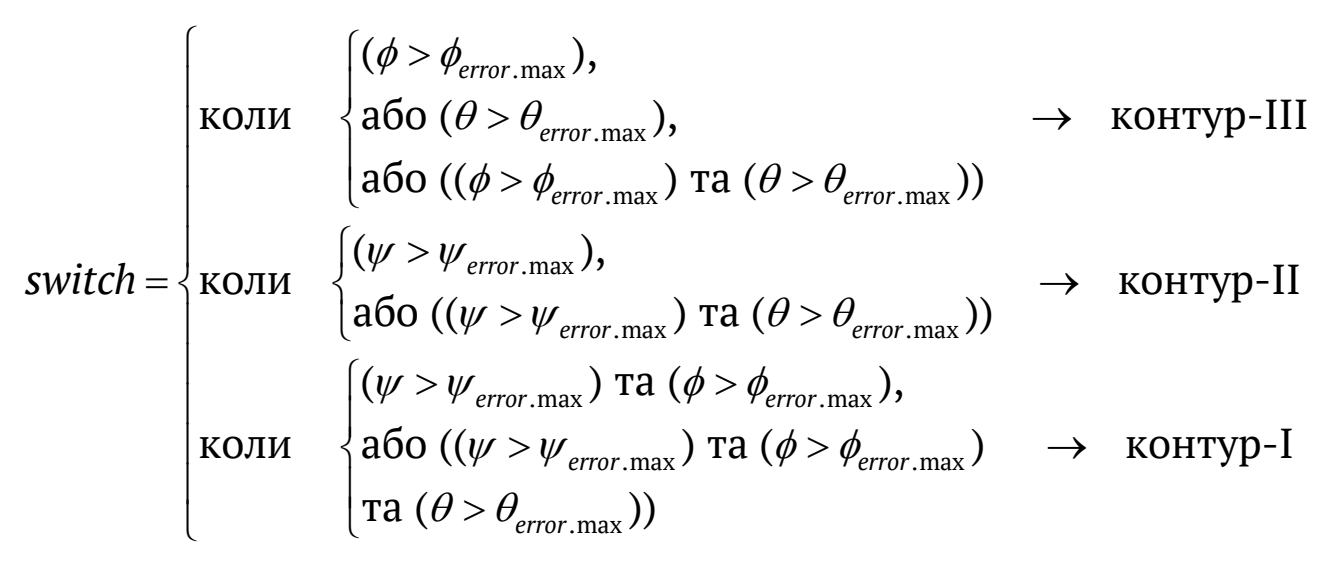


International scientific and technical conference Information Technologies in Metallurgy and Machine building - ITMM 2020

де switch- функція переключання контурів керування; $\psi, \phi, \theta-$ поточні значення кутів рискання, крену і тангажу; $\psi_{\text {error.max }}, \phi_{\text {error.max }}, \theta_{\text {error.max }}$ максимально допустиме значення відхилення за кожним кутом.

Із застосуванням комп’ютерного моделювання було встановлено, що при застосуванні алгоритмів (1) і (2) КА з АМСВ є керованим і зберігає стійкість при максимально допустимому значенні похибки 0,2 радіани за кожним кутом. В свою чергу витрати бортової енергії за визначений період спостерігалися значно менші у порівнянні із застосуванням традиційних методів керування.

Висновки. Встановлено, що застосування методів рухомого керування для здійснення грубої стабілізації КА з АMCВ за допомогою магнетторків дозволяє значно зменшити витрати бортової електричної енергії КА на керування. Зменшення витрат бортової електричної енергії $є$ головним критерієм застосування АМСВ в довготривалих місіях 3 відведення відпрацьованих КА. Таким чином, використання додаткового ресурсу магнетторків КА і методів рухомого керування може бути ефективним методом стабілізації КА з АМСB, що не можуть бути оснащенні виконавчими органами 3 поворотними постійними магнітами. В свою чергу, застосування додаткового ресурсу магнетторків потребує працездатності системи орієнтації і магнітометрів. Звідси, для застосування АMCB, термін експлуатації цих систем повинен бути розрахований з урахуванням етапу керованого відведення.

\section{Література}

1. Lapkhanov E. Khoroshylov S. Development of the aeromagnetic space debris deorbiting system // Eastern-European Journal of Enterprise Technologies. - 2019. - Vol. 5. Iss. 5(101). - P. 30 - 37. DOI: 10.15587/1729-4061.2019.179382

2. Алпатов А. П. Динамика космических летательных аппаратов // НПП Видавництво «Наукова думка». - 2016. - 488 с..

3. Динамика космических аппаратов с магнитными системами управления / Алпатов А. П. и др., М: Машиностроение. - 1978. - 200 с.

\section{APPLICATION OF MOBILE CONTROL METHODS FOR STABILIZATION OF A SPACECRAFT WITH THE AEROMAGNETIC DEORBITING SYSTEM}

\section{Lapkhanov Erik}

Abstract. The research of application of the methods of mobile control for the providing of the rough stabilization of the spacecraft (SPC) with the aeromagnetic deorbiting system (AMDS) is carried out in the work. 
In turn, AMDS consists of two submodules: an aerodynamic flat sailing element and electromagnetic executive devices. The electromagnetic executive devices serve to orient and stabilize the aerodynamic flat sailing element perpendicular to the dynamic flow of the incoming atmosphere. It has been established that providing such stabilization for the flat sailing aerodynamic elements increases the aerodynamic braking force by $40-50 \%$ and reduces the deorbiting time by $25-30 \%$. However, for the effective functioning of such systems, the main criterion is the minimization of on-board power consumption in long-term space missions of the deorbiting of spent spacecraft from working orbits.

On this basis, it has been proposed to apply the mobile control methods to the electromagnetic executive devices (magnetorquers) by means of which the aerodynamic element is roughly stabilized. It is established that when using the methods of mobile control, the on-board energy consumption can be reduced by an order of magnitude.

Keywords: SPACECRAFT, AERODYNAMIC DEORBITING SYSTEM, AERODYNAMIC FLAT SAIL ELEMENT, MOBILE CONTROL METHODS.

\section{References}

1. Lapkhanov E. Khoroshylov S. Development of the aeromagnetic space debris deorbiting system // Eastern-European Journal of Enterprise Technologies. - 2019. - Vol. 5. Iss. 5(101). - P. 30 - 37. DOI: 10.15587/1729-4061.2019.179382

2. Alpatov A. P. Spacecraft dynamics (in Russian) // Publishing "Naukova dumka". - 2016. - 488 p.

3. Dynamics of spacecraft with magnetic control systems: monography (in Russian) / Alpatov A. P. and others., M: Mashinostroenie. - 1978. - 200 p. 